An early medieval polychrome-enamelled brooch from Flaxengate, Lincoln:

continental fashions in an Anglo-Scandinavian town

Letty ten Harkel (University of Oxford)

Rosie Weetch (British Museum)

With a contribution by Victoria Sainsbury (University of Oxford)

Abbreviated title: An early medieval polychrome-enamelled brooch from Flaxengate

4212 words (excluding notes and bibliography)

Letty ten Harkel

Institute of Archaeology

34-36 Beaumont Street

Oxford OX1 2PG

letty.tenharkel@arch.ox.ac.uk 


\title{
An early medieval polychrome-enamelled brooch from Flaxengate, Lincoln: continental fashions in an Anglo-Scandinavian town
}

\author{
Letty ten Harkel, ${ }^{\mathrm{i}}$ Rosie Weetch ${ }^{\mathrm{ii}}$ and Victoria Sainsbury ${ }^{\mathrm{iii}}$
}

This short contribution discusses an early medieval copper-alloy disc with polychrome enamel from Lincoln (England), held by 'The Collection: Art and Archaeology in Lincolnshire', and identified as a brooch dated to the tenth century and of probable continental manufacture. Only four brooches of this type are currently known, three of which were found in England, with a fourth from France. Following discussion of its stylistic characteristics and metallurgical composition, we discuss the implications of the Lincoln find for the understanding of the relationship between the area of the Danelaw and the continent, highlighting a growing body of evidence for the popularity of continental 'fashions' in areas of Scandinavian settlement.

In 1973, during excavations on the Flaxengate site in Lincoln (fig. 1) by the City of Lincoln Archaeology Unit (CLAU), a severely damaged enamelled copper-alloy convex mount came to light. Although the object was conserved and restored, due to circumstances beyond the control of the CLAU the early medieval metalwork from Lincoln was never published. ${ }^{\text {iv }}$ More recently, it was re-identified as a brooch similar to published discoveries from a 'Viking' grave in Cambois, Bedlington, Northumberland (dated to the ninth century), ${ }^{\mathrm{v}}$ Hyde Abbey, Winchester (dated to the tenth century or later), ${ }^{\mathrm{vi}}$ and from the castle at Villejoubert, Charente (southwest France) (dated to the late 
tenth or early eleventh centuries). ${ }^{\text {vii }}$ The enamelled brooch from Lincoln also closely relates to a group of polychrome-enamelled brooches from the eastern Alps region. ${ }^{\text {viii }}$ Since the late nineteenth century, these polychrome-enamelled brooches were considered part of the material assemblage thought to be diagnostic of the so-called 'Kettlach/Köttlach' culture, named after the cemetery in Austria where a number or these brooches, and other jewellery items, were excavated in 1853 . $^{\mathrm{ix}}$ The brooch is almost certainly of pre-Conquest date (see discussion below), but the find was associated with a late eleventh-century levelling layer between two construction phases of the Flaxengate buildings. As the Lincoln find is only the third of this type to be recognised in England, this contribution discusses the implications of the discovery for our understanding of the identities of the inhabitants of early medieval Lincoln as well as the significance of this brooch-type in its wider, European context.

\section{THE BROOCH}

The brooch (F72 <ae296>, figs 2-3) was originally found in three separate pieces, but was subsequently partially reconstructed. The object is cast copper-alloy and measures $c$. $43 \mathrm{~mm}$ in diameter. It has a raised central roundel with a diameter of $25 \mathrm{~mm}$, decorated with red, green, white and blue champlevé enamel surrounding a bird motif. Although part of the central roundel is missing, the bird seems to have been similar to the betterpreserved Winchester and Cambois (fig. 4) specimens, with a slightly fan-shaped tail touching the border, a raised wing and holding a branch in its beak. The details of the bird are incised like those on the Winchester brooch, whilst the details of the bird motif on the Cambois brooch are executed in punched dots. The raised inner roundel is set 
within a wider border cast in relief, part of which has been reconstructed. Corrosion renders the pattern difficult to interpret, but again it is similar to the Winchester (characterised as 'formless') ${ }^{\mathrm{x}}$ and Cambois (characterised as 'fish-like heads with gaping mouths and pellet eyes' $)^{\mathrm{xi}}$ examples. The outside edge has a border of close-set incised lines creating a twisted rope-like effect. The underside of the brooch is concave and undecorated.

No attachment fittings survive, similar to the others in this group, but there is evidence that they all functioned as brooches. The Cambois and Villejoubert specimens have corrosion marks and soldiering joints in arrangements and locations appropriate for pin fittings. The Winchester brooch has one side of the pin fitting remaining - this has been riveted through the front of the brooch, not taking into account the design, suggesting that it was a later addition. ${ }^{\text {xii }}$ This could be evidence of a repair, or the later conversion of the object into a brooch. Microscopic analysis of the Lincoln object revealed striation marks and significantly less corrosion on the back than on the front. This may indicate that any attachment lugs or their remains were accidentally removed during the conservation process, or may be evidence of the re-use or repurposing of the brooch in the past (figs 2-3). The latter possibility may also apply to the French example, as striations were identified across the entire reverse surface of the brooch including the three soldiering joints interpreted as original attachment fittings. ${ }^{\text {xiii }}$ Given the close similarities between this group both in terms of style and size, it therefore seems likely that all were originally brooches, but that some were later either repaired or adapted for a different use. The evidence for re-use of these objects suggests they were perhaps considered valuable or high-status objects. 


\section{THE DISCOVERY OF THE BROOCH}

The brooch was discovered in context F72 (AIB) in area B of the 1973 Flaxengate excavations. (AIB) was described on the context sheet as a clean layer of medium to dark brown loam with stones, and interpreted as levelling over Structure 20 (S20) for Structure 26 (S26), fronting onto Grantham Street. During post-excavation phasing, the context was assigned to Period VII, of later eleventh-century date (c. $1060 / 70$ to $1080 / 90){ }^{\text {xiv }}$ S20 was directly overlying two earlier buildings (S17, dated to the first half of the eleventh century, and S13, of late tenth- to early eleventh-century date). ${ }^{\mathrm{xv}}$ This sequence of buildings (S13, S17 and S20) was associated with industrial activities including metalworking, leading to their identification as workshops, although it was acknowledged that they could have fulfilled a range of functions. S20 stood out in particular for being associated with a large quantity of finished and unfinished copper-alloy hooked tags and some evidence for silver working. ${ }^{\text {xvi }}$

Although the Flaxengate excavations, which took place over the course of several years in the 1970s, remain the most extensive investigations into Lincoln's early medieval occupation, the site was not without its methodological challenges. ${ }^{\text {xvii }}$ The excavations provided a unique insight into the development of a series of buildings, seemingly in single ownership, as periodic levelling and rebuilding took place across the site as a whole. In terms of the artefactual material, it was noted that these frequent landscaping activities resulted in high levels of residuality and a lack of secure stratification of objects, with the majority of artefacts coming from levelling and demolition layers between building phases. ${ }^{\text {xviii }}$ The later eleventh-century date of the 
context containing the brooch under discussion here therefore only provides a terminus ante quem for its production, offering no solution to the discrepancy in dating between its parallels from Cambois and Winchester, noted above. ${ }^{\text {ix }}$

\section{THE LINCOLN BROOCH AND STYLISTIC PARALLELS}

As stated above, the Lincoln brooch belongs to a group of polychrome-enamelled brooches with a variety of motifs that were thought to belong to the so-called Kettlach or Köttlach culture. More recently, archaeologists have argued that using the term Kettlach/Köttlach to describe these brooches is misleading, as it ascribes unnecessary cultural and ethnic affiliations to the series, and underplays their connections and similarities with wider trends in European material culture during the late early medieval period. ${ }^{\mathrm{xx}}$ As such the term 'polychrome-enamelled brooch' is preferred as a descriptor. This term still allows us to identify these as a distinct set of objects, based on their use of multi-coloured opaque enamels within the same cell. This is different from the use of one colour per cell as seen on the majority of enamelled brooches found in northwest Europe, especially in northern Germany, the Low Countries, and England.

Polychrome-enamelled brooches have a distribution focused on the eastern Alps region, where they are found mainly in funerary contexts, spanning east from Switzerland, through Austria and northern Italy into Slovenia, and north towards Frankfurt in Germany. ${ }^{\mathrm{xxi}}$ Whilst this still best describes the core distribution of polychrome-enamelled brooches, there are a growing number of outliers. The number of examples from England with a variety of motifs has increased significantly since the introduction of the Portable Antiquities Scheme, and the encouraged recording of metal- 
detected finds. ${ }^{\text {xii }}$ Further examples with a central motif of a back-turned animal or a cross have recently become known in Denmark. ${ }^{\text {xiii }}$ The increasingly widespread discoveries of these brooches suggests that their traditional distribution pattern may have been influenced by the primary method of deposition (as grave goods) and subsequent recovery. ${ }^{\text {xxiv }}$

The polychrome effect achieved with the enamel on this range of brooches creates a vibrant background to a central silhouetted motif. ${ }^{\mathrm{xxv}}$ The subject of the central motif varies greatly across the series, with crosses, back-turned animals, the Agnus Dei, and birds all proving popular. Birds on polychrome-enamelled brooches are shown either facing forward with their head turned and wings outstretched, or shown in profile like the brooch from Lincoln. ${ }^{\text {xxvi }}$ Whilst most of the birds on these broches are shown without any additional features, the one on the Lincoln brooch would have held a short two-pronged branch in its beak. This particular iteration of the bird motif is found on just six other polychrome-enamelled brooches. One comes from the Kettlach/Köttlach cemetery itself, but unlike the bird on the Lincoln brooch this bird looks backward over its wing, and grasps a two-pronged branch in its beak. ${ }^{\text {xxvii }}$ Two recently metal-detected polychromeenamelled brooches from Bavaria, Germany, also feature the bird-with-branch motif, and their elaborate tails suggest that they may represent peacocks. ${ }^{\text {xxviii }}$ Whilst these three polychrome-enamelled brooches have similar motifs to the Lincoln brooch, none features the moulded border.

The other three known occurrences of the bird-with-branch motif on polychromeenamelled brooches are all remarkably similar to the Lincoln brooch: the bird faces the same direction on all brooches; all have the moulded border; and all have a raised wing. 
The first was discovered in 1859 in a burial in Cambois, Northumberland, along with a bone comb and three bodies. ${ }^{\text {xxix }}$ The second, found at uncertain date, is recorded as coming from Hyde Abbey, Winchester. ${ }^{\mathrm{xxx}}$ The third brooch was found during the more recent excavations of a castle in Villejoubert, Charente (southwest France). ${ }^{\mathrm{xxxi}}$ Unlike the Lincoln brooch, these three brooches are complete and in very good condition: the enamels are still bright and the moulding and decoration are clear (compare fig. $\mathbf{3}$ and fig. 4). The Lincoln brooch and these three parallels are identical in form and concept, and whilst establishing if any are mould duplicates is difficult without close analysis of all the original objects, which was beyond the scope of the current study, it seems likely that they were products of the same workshop.

\section{PLACE OF MANUFACTURE OF THE LINCOLN BROOCH}

Just a few decades ago, the two examples from Winchester and Cambois stood out as strange and difficult to explain in the context of late Anglo-Saxon metalwork, so it is not surprising that their origin was debated. Based on their exclusive occurrence in England, David Wilson and David Hinton argued that both these brooches were of English manufacture. ${ }^{\text {xxii }}$ However, the recent discovery of the example from Villejoubert reveals how quickly our picture of object distributions can change in light of new finds.

Wilson and Hinton both thought that that whilst the Winchester and Cambois brooches' use of polychrome enamel linked them to the wider range of polychromeenamelled brooches of the eastern Alps region, the motif was definitely of English origin. ${ }^{\text {xxxiii }}$ This argument was supported by the find of two bone spoons from Winchester 
decorated with bird-with-branch motifs, and a third bone spoon with this motif, also from Winchester, has subsequently been discovered. ${ }^{\text {xxiv }}$ But the character of the birds on the bone spoons is quite different to the brooches. The use of bird motifs on polychromeenamelled brooches is very common, and we have already seen that the bird-with-branch motif was not restricted to the Lincoln brooch and its English parallels, but was also in use on the continent. Further, there is nothing about the bird with branch motif to suggest specifically English origin, and it is just as likely that it derives from a continental tradition of bird representation. Vera Evison argued that there were no truly compelling parallels for the bird motif in Anglo-Saxon art, and, significantly, as there is currently no clearly diagnostically Anglo-Saxon metalwork that employs this very distinctive enamelling technique, Evison suggested that a continental origin was preferable. ${ }^{\mathrm{xxx}}$

The debate surrounding the place of manufacture of polychrome-enamelled brooches with bird-with-branch motifs continues. Metallurgical analysis had already been carried out on the Cambois, Villejoubert and Austrian brooches (no metallurgical analysis of the Winchester brooch has been carried out to date). ${ }^{\mathrm{xxxvi}}$ There is also a more extensive programme of analysis under way in Austria to determine the likely source of raw materials for a number of object types including polychrome-enamelled brooches ${ }^{\mathrm{xx} x v i i}$ Victoria Sainsbury of the Oxford Research Laboratory for Archaeology and the History of Art (RLAHA) therefore investigated the Lincoln brooch by ED-XRF to shed light on its metal composition, allowing comparison with the Cambois and Villejoubert brooches as well as the Austrian brooch group, and - given the context in which the brooch was found - with contemporary metalworking debris from Flaxengate, including an assemblage of unfinished hooked tags. ${ }^{\text {xxxviii }}$ As the Lincoln brooch is heavily corroded, 
the front more so than the back, any analysis is, at best, speculative. The results of the metallurgical analysis are detailed in Table $\mathbf{1 .}$

Despite any reservations, when the results of the analyses were compared to other enamelled brooches and the scrap from Flaxengate, it did show up some interesting details. Comparison was hindered slightly by the fact that for the Cambois brooch only average values were published, whilst the results of the Austrian brooch-group, consisting of just over 20 brooches, were given in graph-form rather than as absolute values. The comparative average values for the Lincoln, Cambois and Villejoubert brooches are given in Table 2, revealing that although the largest component in the alloys of all three brooches was copper, and lead occurs in relatively constant quantities, the values for zinc and especially tin vary significantly. Although it is difficult to comment on zinc in highly corroded objects, the implications for the variations in tin, which were consistently below $1 \%$ in the Lincoln brooch, are discussed more fully below.

The analysis of the Austrian brooch-group is published elsewhere, ${ }^{\text {xxix }}$ but a narrative summary will be given here. Prior to analysis of the Austrian brooches it was hypothesised that the alloys would probably consist of relatively pure copper $(>80 \%)$ with small quantities of tin and/or lead ('bronze'), as copper-zinc alloys ('brass') would be less suitable for enamelling. However, the results of the analysis of the brooches were surprising: the alloys were remarkably consistent across the analysed assemblage, and although copper did indeed make up by far the largest percentage of the alloys $(>70 \%$ in all instances), the other significant components were lead ( $<10 \%$ in all instances) and zinc (between $10-20 \%$ ). Tin, on the other hand, made up $1 \%$ or less of the alloys, as was the case in the Lincoln brooch. ${ }^{\mathrm{xl}}$ 
The analysed Flaxengate assemblage of scrap metal was extremely variable in nature, consisting of spillages, bars and bar ingots, wire, sheet metal, unfinished hooked tags and some miscellaneous other objects, broadly dated to the later ninth to twelfth centuries with some later outliers. Unsurprisingly perhaps, given the variation in the analysed sample and the broad date range, the analysis showed a wide variety of alloys including both 'brasses' and 'bronzes' xli Having said that, copper-zinc alloys outweighed copper-tin alloys: some $85 \%$ of residues from crucibles used for copper-alloy were zincrich. This pattern is unsurprising, as brass was supposedly reintroduced in Britain in the later Anglo-Saxon or Anglo-Scandinavian periods. ${ }^{x \text { lii }}$ Despite this, the tin content of the Flaxengate scrap material was consistently higher than that of the Lincoln brooch, with only very few examples below $1 \%$ xliii $^{\text {in }}$

In conclusion, it seems that the metal composition of the Lincoln brooch - a copper-zinc alloy with less than $1 \%$ tin - is most consistent with the Austrian assemblage of polychrome-enamelled brooches from the eastern Alps region. Interestingly, there is a clear disparity with the Villejoubert brooch - stylistically a closer parallel to the Lincoln brooch than the Austrian assemblage - as tin is present in much more significant quantities. Although tin tends to be preferentially apparent in corrosion material, the readings from the French brooch were consistently high, whilst those from the Lincoln brooch were consistently low. ${ }^{\text {xliv }}$

The results of the metallurgical analysis of the brooch have interesting implications. Although the context in which the object was found might have suggested a Lincoln-based production centre, the average tin content of the brooch differs for the scrap-metal and unfinished hooked tags found on the same site. Further, based on its use 
of polychrome enamel, which as stated is not a feature of Anglo-Saxon metalwork, it therefore seems most likely that the Lincoln brooch was created in a continental workshop, and thus represents the import of a continental object into Anglo-Scandinavian England.

Further, if the Lincoln, Cambois, Winchester and Villejoubert brooches were indeed products of the same workshop, the dissimilarity in their composition can only be explained if the metalworkers used scrap metal from multiple sources rather than freshly mined raw materials. This exists in contrast with preliminary conclusions from the programme of scientific analysis of the Austrian brooches, which concluded that the consistency of the metal composition of ninth- to tenth- century objects implies that the use of recycled materials at this time was unlikely. ${ }^{x l v}$ Perhaps the four near-identical brooches from Lincoln, Winchester, Cambois, and Villejoubert were a distinct sub-group, with a separate continental production centre from the Austrian examples.

\section{DATING OF THE LINCOLN BROOCH AND ITS PARALLELS}

Polychrome-enamelled brooches appear to have emerged in the later part of the ninth century, and continued into the eleventh. ${ }^{\text {xlvi }}$ Although the circumstances of discovery of the Lincoln brooch offer no firm clues for an exact date beyond a terminus ante quem in the eleventh century, the date of the Lincoln brooch and its parallels can be further refined through both art-historical and archaeological analysis. The motif of the birdwith-branch should be seen as relating to Christian iconography in some way. Hinton has suggested that it may be a conflation of multiple motifs, including the bird-in-vine 
motif, ${ }^{x l v i i}$ which ultimately derives from Mediterranean models and relates to the protective qualities of the vine through referencing Jesus' words in John 15:1 'I am the true vine'. The motif becomes almost ubiquitous in later Anglo-Saxon art appearing across the full range of art mediums, including metalwork, sculpture, and manuscripts. The bird on the Lincoln brooch and its parallels are not shown inhabiting vine scrolls (unless one takes the outer moulded decoration of the brooches as representative of the vine, although this still would not explain the branch in the birds' beak), but they could be argued to represent a simplified abbreviated version of the motif. Another possibility is that the motif represents the dove that returns to Noah with an olive branch. This motif appears in early medieval manuscripts as part of a wider scene including Noah's Ark (such as in the eleventh century Cotton Claudius B. IV, f.15v). Whilst the motif on the Lincoln brooch and its parallels lack the contextual scene setting of Noah's Ark, its identification as such seems entirely plausible. Either interpretation means that the brooch relates to a variant of polychrome-enamelled brooches found in the eastern Alps region with Christian imagery, which includes crosses and a number of bird motifs (Eichert group C3). This group has been dated to the tenth century based on the radiocarbon dates derived from the burials in which they were deposited. ${ }^{\text {xlviii }}$

The varying contexts of the examples from England could all accommodate a tenth century date. The brooch from the burial in Cambois was given a deposition date of no later than the middle of the tenth century (although the brooch itself was given a ninthcentury date), as it was found with a bone comb of the handled type (Ashby Type 3), which has recently been dated to the eighth to eleventh centuries. ${ }^{\text {xlix }}$ The example from Winchester is unstratified, but the city expanded and grew in prosperity during the tenth 
and eleventh centuries. The damaged example of polychrome-enamelled brooch, but with a back-turned animal motif, from Fishergate in York, finally, was excavated from a pit dated to the site's Period $4 \mathrm{z}$ of the eleventh to twelfth century. ${ }^{1}$ Given these various parallels, a tenth-century date for the Lincoln brooch seems most likely.

\section{CONTINENTAL FASHIONS AT FLAXENGATE IN THE TENTH CENTURY?}

Given Lincoln's inclusion in a loose grouping of 'urban' settlements in the East Midlands known as the Five Boroughs (burga fife), which according to the Anglo-Saxon Chronicle were 'freed' from heathen Northmen by King Edmund in AD 942, the town is commonly ascribed an Anglo-Scandinavian identity. ${ }^{\text {li }}$ Evidence for Scandinavian and AngloScandinavian metalwork is indeed present, including a Jellinge-style brooch of possible Scandinavian manufacture, a strap-end of Thomas Type 4 (a multi-headed strap-end in devolved Borre-style) and a flat Borre-style brooch of a type particularly common in East Anglia, whilst evidence for Hiberno-Norse fashions is apparent from the presence of two ring-headed pins of a type commonly found in Dublin. ${ }^{\text {lii }}$

More recently, however, Gabor Thomas has argued that the introduction of 'continental' object types in 'Anglo-Scandinavian' England during the Viking Age was

more common than has traditionally been given credit. liii Recent research drawing on the expanding corpus of metal-detected finds has shown that brooches, and indeed other dress-accessories, of continental origin or inspiration are quite common in AngloScandinavian England. ${ }^{\text {liv }}$ As mentioned, when the Winchester and Cambois brooches were first discussed they were the only examples of their kind to have been found in England, but the number and types of recorded polychrome-enamelled brooches from 
England have grown since. The latest example is a metal-detecting find recorded in 2012 from Itteringham, Norfolk, featuring a front-facing bird with out-stretched wings. ${ }^{\text {lv }}$ Other examples include three with back-turned animal motifs: two metal-detected finds with missing enamel - one from Ashwell, Hertfordshire ${ }^{\mathrm{lvi}}$ and the second from Riddlesworth, Norfolk $^{\text {lvii }}$ - and the above-mentioned example from Fishergate, York, which was originally recorded as a mount. ${ }^{\text {lviii }}$ Two further examples were first published in 1966, and whilst they have lost their enamel they are clearly part of the same typology. ${ }^{\text {lix }}$ In this context the brooches from Lincoln, Cambois, and Winchester look far less exotic: instead they are part of a wider fashion for continental styles in Anglo-Saxon England.

There is more evidence for 'continental'-style artefacts from Lincoln itself as well. The only other imported Frankish dress-accessory recognised to date is a ninth-century belt buckle from St Paul-in-the-Bail. ${ }^{\mathrm{lx}}$ However, other artefacts occur that are based on continental prototypes, but are of probable English manufacture. These include a number of eighth- to tenth-century ansate brooches, a type of bow brooch with symmetrical terminals that were inspired by fashions emanating from the near-continent. ${ }^{1 \times i}$ There are also two near-identical tenth-century lead-alloy flat disc-brooches decorated with a stylised curved-armed cross-design in low relief, which may have been produced in Lincoln itself. This type of disc brooch has a distribution across large parts of north-west Europe. Evidence for the production of continental-inspired metalwork in Lincoln also comes from the evidence of moulds used for the production of continental-style tongueshaped strap-ends with abstract foliate decoration. ${ }^{\text {Ixii }}$ Finally, the import of continental pottery into England seems to have declined sharply in comparison to the heyday of the wics, but the pottery that was produced in Lincoln and other Anglo-Scandinavian 
production centres from the second half of the ninth century - often attributed to the introduction of continental potters in England, either at the time of the Scandinavian settlement or during periods of Anglo-Saxon control - bore strong similarities to continental pottery types. $^{\text {1xiii }}$

It has been noted that the use of continental style dress accessories in England is largely limited to the area of the Danelaw, and that their distribution overlaps with that of Scandinavian and Anglo-Scandinavian brooches with concentrations in Lincolnshire and East Anglia. ${ }^{\text {lxiv }}$ What is more, if the grave from Cambois, Bedlington is indeed a 'Viking' grave, as suggested by Alexander, it provides a direct parallel for the deposition of a continental polychrome-enamelled brooch in an Anglo-Scandinavian context, and it is possible to suggest also that the brooch from Villejoubert can be related to Viking activity in the area at this time. ${ }^{\mathrm{lxv}}$ However, the polychrome enamelled disc-brooch from Winchester and the related object from Ashwell, Hertfordshire, serve as a reminder that continental influences were not restricted to areas of Scandinavian settlement alone.

In short, it is clear that new 'cosmopolitan' fashions enjoyed renewed popularity in the Anglo-Scandinavian period, and the brooch from Lincoln is part of this picture of the broad cultural influences affecting dress practices in England. The question that remains concerns the mechanisms behind the increasingly widespread distribution of continental and other metalworking styles across north-west Europe. Although the Scandinavian raids and settlement may have caused significant disruption of the established socioeconomic order, this went hand in hand with the creation of new possibilities. The high degree of mobility that characterised the Viking period also paved the way for the movement of objects across large regions through channels old and new, and by the end 
of the tenth century, a different economic landscape had emerged. Emerging towns like Lincoln and Winchester - mass-production centres of portable material culture - were one of the prime characteristics of this new age.

\section{BIBLIOGRAPHY}

Adams Gilmour, L 1988, Early Medieval Pottery from Flaxengate, Lincoln, The Archaeology of Lincoln 17.2, London: Council for British Archaeology for the Trust for Lincolnshire Archaeology.

Ashby, S 2011, 'An atlas of medieval combs from northern Europe', Internet Archaeology 30.

Alexander, M 1987, ‘A 'Viking-Age’ grave from Cambois, Bedlington, Northumberland', Medieval Archaeology 31, 101-5.

Baastrup, M 2009, ‘Småfibler af Karolingiske og ottonske typer i Danmark’ Aarbøger for Nordisk Oldkyndighed og Historie 2005, 209-55.

Bayley, J 2008, Lincoln: Evidence for Metalworking on Flaxengate and other Sites in the City: Technology Report, Portsmouth: English Heritage Research Department Report 67-2008.

Blinkhorn, P 2013, 'No pots please, we're Vikings: pottery in the southern Danelaw, 8501000', in Hadley and Ten Harkel, 157-71.

Bourgeois, L and Biron, I 2009, 'La fibule émaillée', in L Bourgeois, Une résidence des comtes d'Angoulême autour de l'an mil: le castrum d'Andone (Villejoubert, 
Charente): fouilles d'André Debord (1971-1995), Caen: Publications du Centre de Recherches Archéologiques et Historiques Médiévales, Brepols, 25-130.

Collis, J and Kjølbye-Biddle, B 1979, 'Early medieval bone spoons from Winchester' in The Antiquaries Journal 59.2, 375-91.

Cool, H E M 2011, 'The small finds' in Digital Section 3: Winchester, A City in the Making - Specialist Reports. In: B M Ford and S Teague (eds), Winchester, a city in the making, Oxford Archaeology: Oxford. Available on https://library.thehumanjourney.net/663/.

Eichert, S 2010, 'Die frühmittelalterlichen Funde aus dem Kirchenfriedhof von St. Peter', in K Karpf and T Meyer (eds), Sterben in St. Peter. Das frühmittelalterliche Gräberfeld von St. Peter bei Spittal/Drau in Kärnten. Beiträge zur Kulturgeschichte Oberkärntens 6, Spittal an der Drau, 148-91.

Eichert, S 2013, 'Zur Absolutchronologie des Ostalpenraums im Frühmittelalter unter besonderer Berücksichtigung 14C-datierter Grabinventare', Bericht der Bayerischen Bodendenkmalpflege 54, 419-28.

Eichert, V S and Mehofer, M 2011, 'Frühmittelalterliche Emailscheibenfibeln aus Villach: Archäometallurgie und experimentelle Archäologie', Museum Der Stadt Villach Jahrbuch 48, 29-66.

Eichert, S and Mehofer, M 2013, 'Recycelte Römer oder slawische Metallurgen? Interdisziplinäre Studien zur frühmittelalterlichen Buntmetallindustrie im Ostalpenraum', Archaeologie Österreichs 24.2, 46-54.

Evison, V 1977, 'An Enamelled Disc from Great Saxham', The Proceedings of the Suffolk Institute of Archaeology 34, 1-13. 
Giesler J 1978, ‘Zu einer Gruppe mittelalterlicher Emailscheibenfibeln', Zeitschrift für Archäologie des Mittelalters 6, 57-72.

Hadley, D M and Ten Harkel, L (eds) 2013, Everyday Life in Viking-Age Towns: Social Approaches to Towns in England and Ireland, c. 800-1100, Oxford: Oxbow.

Hinton, D 1990, 'Disc and rectangular brooches', in M Biddle (ed) Object and Economy in Medieval Winchester, Oxford: Clarendon Press, 636-9.

Kershaw, J 2013, Viking Identities: Scandinavian Jewellery in England, Oxford: Oxford University Press.

Mann, J 1982, Early Medieval Finds from Flaxengate I: Objects of Antler, Bone, Stone, Horn, Ivory, Amber, and Jet, The Archaeology of Lincoln 14.1, London: Council for British Archaeology for the Lincoln Archaeological Trust.

Oddy, W A, La Niece, S and Stratford, N 1969, Romanesque Metalwork: Copper Alloys and their Decoration, London: British Museum Publications.

Perring, D 1981, Early Medieval Occupation at Flaxengate, Lincoln, The Archaeology of Lincoln 9, London: Council for British Archaeology.

Pittioni, R 1943, Der frühmittelalterliche Gräberfund von Köttlach, Landkreis Gloggnitz Niederdonau, München: Brünn.

Reigl, A 1923, Die spätrömische Kunst-Industrie nach den Funden in Österreich-Ungarn im Zusammenhange mit der Gesamtentwicklung der Bildenden Künste bei den Mittelmeervölkern Vol.2: Kunstgewerbe des frühen mittelalters, Wien: Österreichische Staatsdruckerei.

Roesdahl, E, Graham-Campbell, J, Connor, P and Pearson, K 1981, The Vikings in England and in their Danish Homeland, London: The Anglo-Danish Viking Project. 
Rogers, N S H 1993, Anglian and other Finds from 46-54 Fishergate, York: Council for British Archaeology.

Rogerson A and Ashley S 2012, 'A selection of finds from Norfolk recorded in 2012 and 2013’ Norfolk Archaeology 46.2, 406-21.

Smedley, N and Owles, E 1964, 'Some Anglo-Saxon “Animal”-Brooches', The Proceedings of the Suffolk Institute of Archaeology 30, 166-77.

Ten Harkel, L 2013, 'Of towns and trinkets: the production and consumption of metalwork in tenth-century Lincoln', in Hadley and Ten Harkel, 172-92.

Ten Harkel, L in prep, “'A small epitome of the whole world": the production and use of non-ferrous dress-accessories and related items from early medieval Lincoln' (submitted to The Antiquaries Journal).

Thomas, G 2012, 'Carolingian culture in the North Sea world: rethinking the cultural dynamics of personal adornment in Viking Age England', European Journal of Archaeology 15.3, 486-518.

Thörle, S 2001 Gleicharmige Bügelfibeln des frühen Mittelalters, Bonn: Habelt.

Vince, A 2003, 'Lincoln in the early medieval era, between the 5th and 9th centuries', in D Stocker (ed), The City by the Pool: Assessing the Archaeology of the City of Lincoln, Lincoln Archaeological Studies 10, Oxford: Oxbow, 141-56.

Weetch R 2013, Late Anglo-Saxon brooches within their northwest European context: a study of social identities between the eighth and eleventh centuries (unpublished PhD thesis: University of Reading).

Williams, G 2013, 'Towns and identities in Viking England', in Hadley and Ten Harkel, 14-34. 
Wilson D M 1975, 'Tenth Century Metalwork', in D Parsons (ed), Tenth Century

Studies: Essays in Commemoration of the Council of Winchester and Regularis

Concordia, Pillimore: London, 200-7.

Young, J and Vince, A 2005, A Corpus of Anglo-Saxon and Medieval Pottery from

Lincoln, Lincoln Archaeological Studies 7, Oxford: Oxbow.

\section{ACKNOWLEDGEMENTS}

Many thanks must go to Anthony Lee of 'The Collection: Art and Archaeology in Lincolnshire' in Lincoln for allowing the brooch to leave the museum for analysis and illustration, and for his patience and cheer in dealing with many enquiries. Thanks must go as well to Jenny Mann, whose enthusiasm and assistance in coming to grips with the Flaxengate finds have been invaluable. We also thank Barry Ager (British Museum) and Stefan Eichert (University of Vienna) for drawing our attention to many parallels from the continent, both published and unpublished. The comments of two anonymous peerreviewers helped to improve the clarity of the paper.

\section{FIGURE CAPTIONS}

FIG 1

Location plan. Drawing by Letty ten Harkel, redrawn after Stocker 2003, fig. 1.1.

FIG 2 
Line drawing of the Lincoln brooch. Drawing by C.Williams, (C) C.Williams.

\section{FIG 3}

Photograph of the Lincoln brooch. Photograph by Ian.R.Cartwright, Institute of Archaeology Oxford.

FIG 4

Photograph of the brooch from Cambois, Bedlington. (C) The Trustees of the British Museum.

\section{TABLE CAPTIONS}

Table 1: Results of ED-XRF analysis of the Lincoln brooch, carried out by Victoria Sainsbury.

Table 2: Average results of ED-XRF analysis of the Lincoln brooch in comparison to those of the brooches from Cambois (published in Oddy et al. 1969) and Villejoubert (published in Bourgeois and Biron 2009).

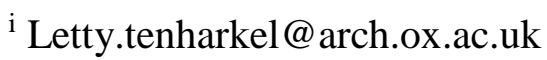

ii RWeetch@britishmuseum.org

iii Victoria.sainsbury@rlaha.ox.ac.uk

iv A selection can be found in Ten Harkel 2013; also see Ten Harkel in prep.

${ }^{v}$ Weetch 2013, cat.264; Alexander 1987.

${ }^{v i}$ Weetch 2013, cat.265; Hinton 1990, 636-7.

vii Bourgeois and Biron 2009

viii Alexander 1987, 102.
} 
ix Reigl 1923; Pittioni 1943.

${ }^{x}$ Hinton 1990, 639.

xi Alexander 1978, 101

xii Alexander 1987, 101-2; Hinton 1990, 638, fig 2011; Bourgeois and Biron 2009, 125-6, fig 3.2.

xiii Bourgeois and Biron 2009, 126.

xiv Perring 1981, 18-21.

${ }^{x v}$ Perring 1981, $12-4$.

xvi Perring 1981, 41; Ten Harkel 2013.

${ }^{x v i i}$ For an overview of the relevant issues, see Perring 1981, 4-5.

xviii Adams Gilmour 1988, 59; Mann 1982, 4.

xix Alexander (1987) dated the Cambois find to the ninth century, whilst Hinton (1990)

preferred a slightly later date, attributing the manufacture of the Winchester brooch to

'Alfredian or later' craftsmen.

${ }^{\mathrm{xx}}$ Eichert 2013, 424; Alexander 1987, 102.

iscussion below.

xxv Eichert and Mehofer 2011.

${ }^{x x v i}$ For the first type, see examples in Eichert 2010, 159; for the second type, see

examples in Eichert 2010, 161-2.

xxvii Reigl 1923, taf. XXVIII 7.

xxviii Eichert pers. comm.

xxix Alexander 1987.

${ }^{x x x}$ Hinton 1990, 636.

xxxi Bourgeois and Biron 2009, 125ff.

xxxii Hinton 1990, 637; Wilson 1975, 204.

xxxiii Hinton 1990, 637; Wilson 1975, 204.

xxxiv Collis and Kjølbye-Biddle 1979; Cool 2011.

${ }^{x x x v}$ Evison 1977, 5.

xxxvi Oddy et al. 1969; Bourgeois and Biron 2009; Eichert and Mehofer 2011.

xxxvii Eichert and Mehofer 2013.

xxxviii Previously published in Oddy et al. 1969, Bourgeois and Biron 2009, Eichert and Mehofer 2011 and Bayley 2008 respectively.

xxxix Eichert and Mehofer 2011, 36, fig. 1.

${ }^{x l}$ Eichert and Mehofer 2011, 32-37.

xli Bayley 2008, 125-9, Tables 31-35.

xlii Bayley 2008, 10.

xliii Bayley 2008, 125-9, Tables 31-35.

xliv Bourgeois and Biron 2009, 126, Table 17.

xlv Eichert and Mehofer 2013, 52.

xlvi Eichert 2013, 425-7.

xlvii Hinton 1990, 637.

xlviii Eichert 2013, 427; 2010, 159-62.

xlix Alexander 1987, 105; Ashby 2011, type 3. 
${ }^{1}$ Rogers 1993, 1354.

${ }^{\text {li }}$ See for example Roesdahl et al. 1981: 95; but see discussion in Williams 2013 on the issues concerning the presumed unity of the 'Five Boroughs'.

lii Ten Harkel 2013, 181; in prep.

liii Thomas 2012.

${ }^{\text {liv }}$ Weetch 2013; Thomas 2012.

${ }^{1 v}$ Rogerson and Ashley 2012, 417.

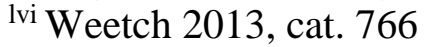

lvii Weetch 2013, cat. 770

lviii Weetch 2013, cat. 766 and cat. 770; Rogers 1993, 1355.

lix Smedley and Owles 1964, XXIVb and c; Weetch 2013, cat. 768, 771.

${ }^{1 x}$ Vince 2003, 154, fig 8.15.

Ixi Thörle 2001

lxii Ten Harkel in prep.; Weetch 2013, 76-7, 155.

lxiii Blinkhorn 2013; Young and Vince 2005; Ten Harkel 2013, 181-4.

lxiv Weetch 2013, 298 ; Kershaw 2013.

lxv Alexander 1987. 